WSRC-CP-2006-00016

Keywords: 2H Evaporator

Flowsheet

Cancrinite

Results of Caustic Dissolution of Aluminosilicate Scale and Characterization Data for Samples from the Evaporator Pot and Gravity Drain Line

W. R. Wilmarth

R. C. Sullivan

C. J. Martino

August 21, 2006

Westinghouse Savannah River Company Savannah River Site

Aiken, SC 29808

Prepared for the U.S. Department of Energy Under

Contract Number DE-AC09-96SR18500

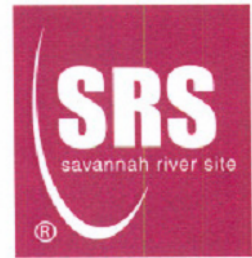




\section{DISCLAIMER}

This report was prepared for the United States Department of Energy under Contract No. DE-AC09-96SR18500 and is an account of work performed under that contract. Neither the United States Department of Energy, nor WSRC, nor any of their employees makes any warranty, expressed or implied, or assumes any legal liability or responsibility for accuracy, completeness, or usefulness, of any information, apparatus, or product or process disclosed herein or represents that its use will not infringe privately owned rights. Reference herein to any specific commercial product, process, or service by trade name, trademark, name, manufacturer or otherwise does not necessarily constitute or imply endorsement, recommendation, or favoring of same by Westinghouse Savannah River Company or by the United States Government or any agency thereof. The views and opinions of the authors expressed herein do not necessarily state or reflect those of the United States Government or any agency thereof. 
Page 3 of 26

\section{Table of Contents}

Results of Caustic Dissolution of Aluminosilicate Scale and Characterization Data for Samples from the Evaporator Pot and Gravity Drain Line........................................................................ 1

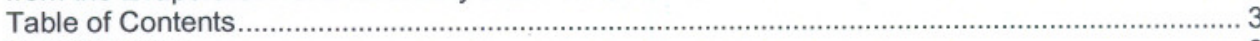

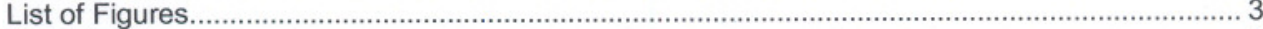

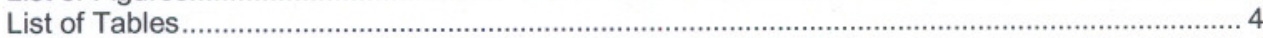

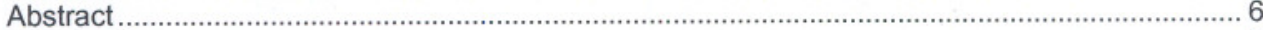

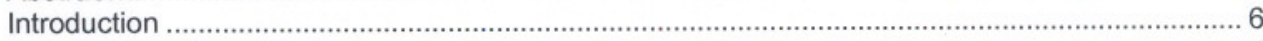

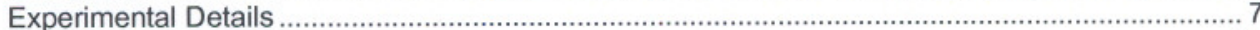

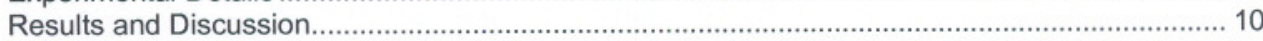

Results of Gravity Drain Line Solids Characterization ............................................ 10

Characterization Data for the Scale Samples from the 2H Evaporator Pot ................. 13

Dissolution Studies of the Gravity Drain Line Scale.................................................. 21

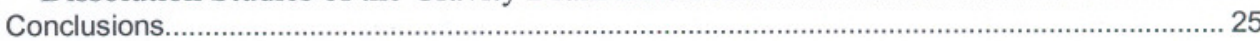

\section{List of Figures}

Figure 1. Photograph of Solids Removed from the Gravity Drain Line (A) and the $2 \mathrm{H}$

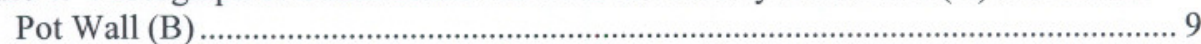

Figure 2. Typical Dissolution Test Apparatus .................................................................. 9

Figure 3. Scanning Electron Microscopy Images of the GDL Scale ................................ 12

Figure 4. Scanning Electron Microscopy Images of Uranium Compounds ..................... 12

Figure 5. Energy Dispersive Spectra from the GDL Scale ............................................. 12

Figure 6. X-ray Powder Diffraction Pattern from the Gravity Drain Line Scale Sample 13

Figure 7. Typical X-ray Diffraction Powder Pattern obtained from the Samples from the

2H Evaporator Pot...................................................................................................... 17

Figure 8: Top: SEM backscatter detector image of a coated grain of scale from the tube bundle (sample HTF-138). Bottom: the corresponding XEDS raster scan of an area of the grain.

Figure 9: SEM secondary electron (top) and backscatter (bottom) images of the surface of a grain of scale from the evaporator tube bundle (HTF-138), magnified 650X... 19

Figure 10: SEM secondary electron (top) and backscatter (bottom) images of the surface of a grain of scale from the evaporator tube bundle (HTF-138), magnified 2000X. 20

Figure 11: Localized XEDS spectra for the uranium-free sodium-aluminosilicate areas (top) and uranium-rich areas (bottom) of the 2- $\mathrm{H}$ evaporator tube bundle scale...... 21

Figure 12. Aluminum Dissolution Data in Various Caustic Solutions ............................ 22

Figure 13. Silicon Dissolution Data at Various Caustic Concentrations ......................... 23

Figure 14. Gelation of Test with 19 M Sodium Hydroxide.............................................. 24

Figure 15. Comparison of the Dissolution of GDL Scale Samples .................................. 24 
W. R. Wilmarth, et al

WSRC-CP-2006-00016

Page 4 of 26

\section{List of Tables}

Table 1. Composition of Gravity Drain Line Samples .... 11

Table 2: Radiochemistry and ICP-MS Results for the 2-Evaporator Pot Scale Samples 15

Table 3: ICP-ES Results for the 2-Evaporator Pot Scale Samples. 
W. R. Wilmarth, et al

WSRC-CP-2006-00016

Page 5 of 26

Approvals:

Authors,

$\begin{array}{rr}\text { W. R. Wilmarth, Chemical Science and Technology } & 8-23-06 \\ \text { Date }\end{array}$

$\begin{array}{lc}\text { R.'C. Sưllivan, Shielded Cells Operations, } & 8-23-06 \\ \text { Date }\end{array}$

$8-23-2006$

C.J.Mamino, hemical Science and Technology $8-23-200$

$\underline{\text { Technical Review }}$

d

K. B. Martin, Chemical Science and Technology

$8-23-06$

Date

\section{$\underline{\text { Management }}$}

J. C/Griffin, Alanager, Chemical Science and Technology $2 / 25 / 06$

D.J. Martin, Tánk Farm Engineering

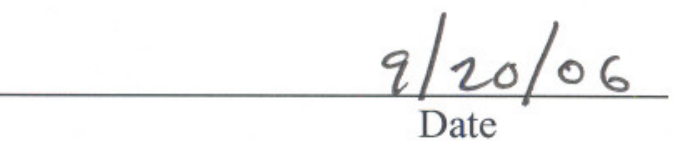




\title{
Results of Caustic Dissolution of Aluminosilicate Scale and Characterization Data for Samples from the Evaporator Pot and Gravity Drain Line
}

W. R. Wilmarth, R. C. Sullivan and C. J. Martino

Savannah River National Laboratory

Washington Savannah River Company

Aiken, SC 29808

\begin{abstract}
The build-up of sodium aluminosilicate scale in the $2 \mathrm{H}$ Evaporator system continues to cause operational difficulties. The use of a nitric acid cleaning operation proved successful in 2001. However, the operation required additional facilities to support spent cleaning solution neutralization and was quite costly. A proposed caustic cleaning flowsheet has many advantages over the acid flowsheet. Therefore, samples were retrieved from the evaporator system (gravity drain line and pot) for both chemical and radiological characterization and dissolution testing.
\end{abstract}

The characterization of these scale samples showed the presence of nitrated cancrinite along with a dehydrated zeolite. Small amounts of depleted uranium were also found in these samples as expected and the amount of uranium ranged from $0.5 \mathrm{wt} \%$ to $2 \mathrm{wt} \%$. Dissolution in sodium hydroxide solutions of various caustic concentrations showed that the scale slowly dissolves at elevated temperature $\left(90^{\circ} \mathrm{C}\right)$. Data from similar testing indicate that the scale removed from the GDL in 2005 dissolves slower than that removed in 1997. Differences in the particle size of these samples of scale may well explain the measured dissolution rate differences.

\section{Introduction}

The Savannah River Site (SRS) stores high-level nuclear waste in 49 underground storage tanks. The wastes are to be vitrified in the Defense Waste Processing Facility (DWPF) for permanent disposal. The available tank space must be managed to ensure viability of the separation canyons to support nuclear material stabilization and continued operation of DWPF. Under normal operations, the wastes are evaporated to reduce volume. The SRS has three operational atmospheric-pressure high-level-waste evaporators. Two evaporators are located in H-Area and one in F-Area. The 242-16 H (or $2 \mathrm{H}$ ) evaporator had not operated from October 1999 to September 2001 due to the presence of a large amount of sodium aluminosilicate scale that contained sodium diuranate. ${ }^{1,2,3}$ The scale is very similar to that observed in the aluminum and pulp paper industries ${ }^{4,5,6}$ and was produced at SRS by reaction of the aluminate supplied by the plutonium separations facilities and the silicate from recycle water from the DWPF. The chemistry of high-level waste with elevated silicon levels thermodynamically favors the 
formation of aluminosilicates. ${ }^{7}$ The $2 \mathrm{H}$ Evaporator contained scale to the point that the concentrated evaporator bottoms could not be removed through normal steam lifting protocol.

Work performed by the Savannah River National Laboratory (SRNL) during calendar years 1998-2000 showed that dilute nitric acid was an effective chemical cleaning agent.

8,9 An overall cleaning flowsheet was developed in calendar year 2000 that addressed numerous safety issues associated with cleaning the pot, neutralizing the uranium-bearing acid and discharging the neutralized solutions to a waste tank. Beginning in May 2001, a depleted uranium and nitric acid mixture was added to the $2 \mathrm{H}$ Evaporator pot and heated to elevated temperatures. As a result of this action, the pot was cleaned and returned to service.

As a result of the formation of aluminosilicates when elevated concentrations of silica are fed to the evaporator, SRS changed the operational requirements for the site's High-Level Waste evaporators. Wastes containing high silicon concentrations, e.g., DWPF recycle would be concentrated in the $2 \mathrm{H}$ Evaporator. The criticality hazard for the $2 \mathrm{H}$ Evaporator was reduced by depleting the U-235 content of the waste below acceptable levels (i.e., depleted uranium). Waste containing aluminate would be processed in the $2 \mathrm{~F}$ or $3 \mathrm{H}$ Evaporator and acceptance criteria were established to monitor for the possible formation of sodium aluminosilicate. ${ }^{10}$

Routine inspections of the $2 \mathrm{H}$ Evaporator pot have been performed bi-annually since the cleaning operations. In a recent inspection, evidence of scale growth has emerged. Additionally, difficulty in lifting the pot contents and reduction in the pot siphon flowrates indicates an obstruction in the Gravity Drain Line (GDL). Therefore, a need to perform chemical cleaning operations has emerged. A caustic cleaning approach is desirable from many aspects, including the chemical compatibility with current processing operations, the avoidance of acid handling and the lack of a need for a neutralization skid. SRNL received samples from the Gravity Drain Line and performed caustic dissolution testing and characterization of these solids along with samples removed from the evaporator pot. ${ }^{11}$

\section{Experimental Details}

This work involved two tasks that are outlined below:

\section{Task 1: Characterization of Evaporator Samples}

Aliquots of the Evaporator samples were submitted for solid state analysis by X-ray powder diffraction (XRD) and energy dispersive spectroscopy - scanning electron microscopy (EDS-SEM) without any in-cell treatment. The intent of these analyses was to determine the crystallographic solid phase and determine if discreet regions of uranium phases exist as in past samples. ${ }^{3}$ Aliquots were prepared using an aqua regia method and 
analyzed for metals by Inductively Coupled Plasma - Emission Spectroscopy (ICP-ES), ${ }^{12}$ plutonium by alpha pulse height analysis using thenoyltrifluoroacetone (TTA) separation, ${ }^{13}$ and other radionuclides by either radiochemical counting techniques or Inductively Coupled Plasma - Mass Spectrometry (ICP-MS). ${ }^{14}$ Samples were submitted independently in triplicate including at least one blank. Additionally, as part of their analysis, Analytical Development included internal standards in each analysis run. Figure 1 shows photographs of samples of the scale removed from the Gravity Drain Line and the $2 \mathrm{H}$ Evaporator pot.

For the samples removed from the pot, $\mathrm{Pu}-239 / 240$ was converted from activity units to $\mathrm{wt} \%$ making the assumption that all activity measured as $\mathrm{Pu}-239 / 240$ was from $\mathrm{Pu}-239$. This leads to conservatively large masses of both $\mathrm{Pu}-239$ and total $\mathrm{Pu}$, versus assuming any other isotopic split between Pu-239 and Pu-240. Mass 238 from ICP-MS is acceptable for use as solely the U-238 mass because $\mathrm{Pu}-238$ contributes an insignificant amount to that mass value $(<0.005 \%)$. The total uranium values provided in the tables are sums of all above-detection-limit values of individual uranium isotopes.

\section{Task 2: Caustic Dissolution Studies}

Initial characterization of solids removed from the GDL in $1997^{15}$ showed that caustic at elevated temperature $\left(90^{\circ} \mathrm{C}\right)$ dissolves the sodium aluminosilicate at rates that could be used in the evaporator pot but were not sufficient for the GDL. Additionally, Dr. AddaiMensah ${ }^{16}$ determined the solubility of a variety of sodium aluminosilicate phases in a number of process fluids. The kinetics of the GDL work and the Addai-Mensah solubility data indicate that caustic chemical cleaning is potentially a viable option. SRNL performed a number of dissolution studies of aliquots of the evaporator samples in a similar manner as used previously. ${ }^{15}$ Figure 2 shows a typical dissolution test setup using a glass beaker and watch glass cover. For the testing, an aliquot of $0.15 \mathrm{~g}$ scale was added to a glass beaker and $30 \mathrm{~mL}$ of acid was added to the beaker and heated to $90{ }^{\circ} \mathrm{C}$ for several hours. Periodically, a $2 \mathrm{~mL}$ aliquot of solution was removed and filtered through a 0.45 micron filter and removed from the shielded cell for analysis. 
W. R. Wilmarth, et al

WSRC-CP-2006-00016

Page 9 of 26

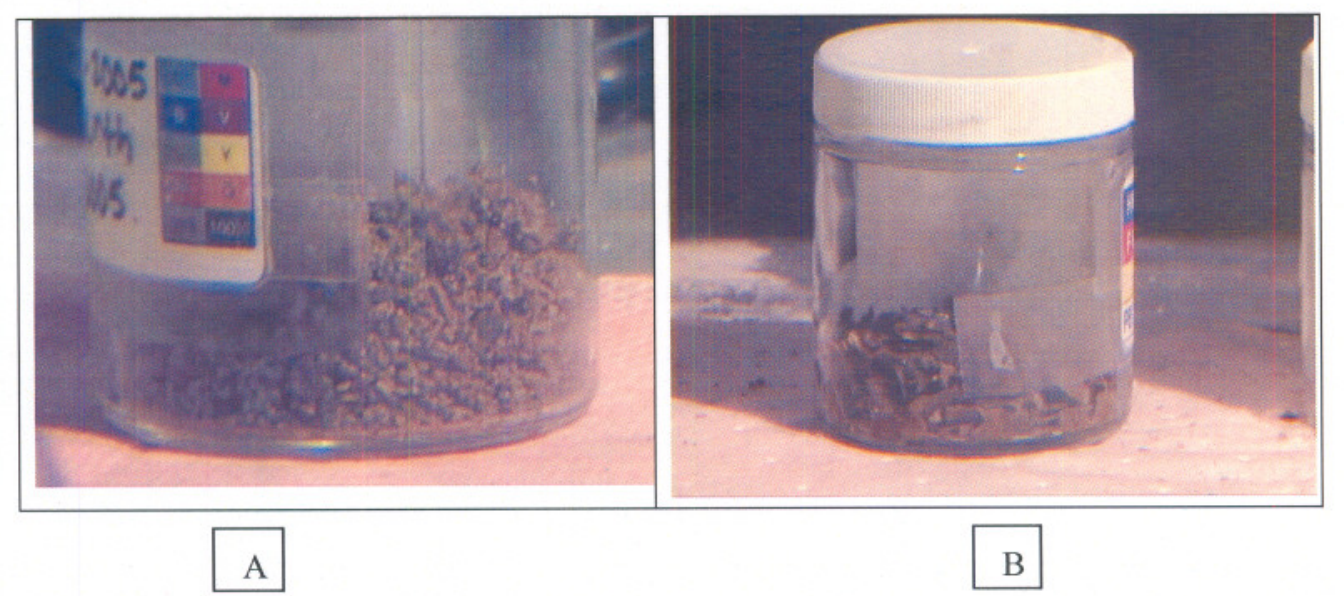

Figure 1. Photograph of Solids Removed from the Gravity Drain Line (A) and the 2H Pot Wall (B)

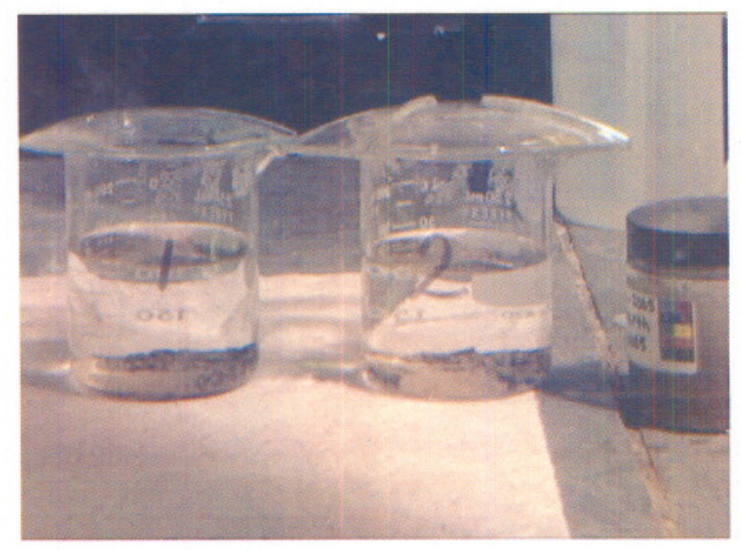

Figure 2. Typical Dissolution Test Apparatus 
Page 10 of 26

\section{Results and Discussion}

\section{Results of Gravity Drain Line Solids Characterization}

SRNL received sample numbered HTF-061 and performed activities to understand the physical properties and chemical and radiochemical composition. Elemental mapping by SEM-EDS characterizes the distribution of uranium in the scale. Sample HTF-061 contained slightly less than $50 \mathrm{~g}$ of scale. Table 1 shows the results of the analyses of a set of triplicate samples and a blank. The material is approximately $10.6 \mathrm{wt} \%$ aluminum and $12.5 \mathrm{wt} \%$ silicon. These values are very similar to that previously analyzed in the Gravity Drain Line. ${ }^{3}$ Due to the sample preparation method, the sodium concentration was not determined. There is limited neutron poison in the scale with the iron concentration being the highest at $0.5 \mathrm{wt} \%$. The uranium concentration averaged $2.59 \mathrm{x}$ $10^{3} \mu \mathrm{g} / \mathrm{g}$ or $0.259 \mathrm{wt} \%$. The uranium enrichment measured $0.498 \%$. There is a small fraction of plutonium in the scale. The Pu-238 and Pu-239 contents are $4.17 \times 10^{6} \mathrm{dpm} / \mathrm{g}$ and $8.41 \times 10^{4} \mathrm{dpm} / \mathrm{g}$, respectively, assuming all of the activity for the $\mathrm{Pu}-239 / \mathrm{Pu}-240$ count is $\mathrm{Pu}-239$. This assumption is conservative from a nuclear criticality perspective.

Aliquots of the scale sample were sent for solid state characterization by Scanning Electron Microscopy, Energy Dispersive Spectroscopy and X-ray powder diffraction. Figure 3 shows typical micrographs of the scale. The first and third images are backscatter images, which show heavy metals such as uranium as bright spots. The second image is a traditional secondary electron image. Figure 4 shows SEM images of a couple of uranium compounds prepared as part of previous studies of the formation of aluminosilicate. ${ }^{17}$ The morphology of the uranium in the GDL scale has similar attributes to both boltwoodite and weeksite. Several Energy Dispersive Spectra were obtained from various regions of the GDL samples examined by this technique. Figure 5 shows two basic spectra obtained from the GDL sample. The first image is the spectra obtained from the aluminosilicate phase and is dominated by the three elements of sodium, aluminum and silicon. Due to the similar concentrations and scattering cross sections of these elements, one can not determine the particular aluminosilicate phase by this technique. Therefore, samples of the GDL scale were submitted for analysis by X-ray powder diffraction. Figure 6 shows the powder pattern obtained from the GDL sample. Two crystalline phases are identified in the powder pattern. The dominant phase is the sodium aluminosilicate phase of cancrinite $\left.\left(\mathrm{Na}_{8} \mathrm{Al}_{6} \mathrm{Si}_{6}\right)_{24}\left(\mathrm{NO}_{3}\right)_{2}-4 \mathrm{H}_{2} \mathrm{O}\right)$ with second minor phase being muscovite a clay phase in the SRS process water. 
Table 1. Composition of Gravity Drain Line Samples

\begin{tabular}{|c|c|c|c|c|c|c|c|c|}
\hline & & ADS Blank & & Evap Scale_1 & & Evap Scale_2 & & Evap Scale_3 \\
\hline Analyte (ug/g) & & 300222055 & & 300222056 & & 300222057 & & 300222058 \\
\hline $\mathrm{Ag}$ & $<$; & 343 & $<$ & 343 & $<$ & 331 & $<$ & 341 \\
\hline $\mathrm{Al}$ & $<$ & 208 & & 106000 & & 109000 & & 104000 \\
\hline $\mathrm{B}$ & $<$ & 263 & $<$ & 263 & $<$ & 254 & $<$ & 261 \\
\hline $\mathrm{Ba}$ & & 57 & & 74.4 & & 81.1 & $<$ & 55.9 \\
\hline $\mathrm{Ca}$ & & 735 & & 1350 & & 1440 & & 1380 \\
\hline $\mathrm{Cd}$ & $<$ & 74.6 & $<$ & 74.6 & $<$ & 72.1 & $<$ & 74.2 \\
\hline $\mathrm{Ce}$ & & 4660 & & 4980 & & 5320 & & 3950 \\
\hline $\mathrm{Cr}$ & $<$ & 177 & $<$ & 177 & $<$ & 171 & $<$ & 175 \\
\hline $\mathrm{Cu}$ & $<$ & 53.1 & $<$ & 53.1 & $<$ & 51.3 & $<$ & 52.8 \\
\hline $\mathrm{Fe}$ & $<$ & 59.5 & & 6480 & & 5510 & & 4220 \\
\hline Gd & & 248 & & 288 & & 297 & & 220 \\
\hline $\mathrm{K}$ & & 10900 & & 10300 & & 11400 & & 9160 \\
\hline La & & 602 & & 669 & & 715 & & 522 \\
\hline $\mathrm{Li}$ & & 597 & & 693 & & 698 & & 539 \\
\hline $\mathrm{Mg}$ & $<$ & 19.8 & $<$ & 19.8 & $<$ & 19.2 & $<$ & 19.7 \\
\hline $\mathrm{Mn}$ & $<$ & 9.91 & & 62.4 & & 50.9 & & 45.9 \\
\hline Mo & $<$ & 659 & & 758 & & 674 & $<$ & 655 \\
\hline $\mathrm{Ni}$ & $<$ & 184 & $<$ & 184.0 & $<$ & 178 & $<$ & 183 \\
\hline $\mathrm{P}$ & $<$ & 1320 & $<$ & 1320 & $<$ & 1280 & $<$ & 1320 \\
\hline $\mathrm{Pb}$ & $<$ & 1290 & $<$ & 1290 & $<$ & 1240 & $<$ & 1280 \\
\hline S & $<$ & 426 & $<$ & 426 & $<$ & 412 & $<$ & 424 \\
\hline $\mathrm{Sb}$ & & 733 & & 1020 & & 1030 & & 833 \\
\hline $\mathrm{Si}$ & $<$ & 2410 & & 125000 & & 128000 & & 121000 \\
\hline Sn & $<$ & 1490 & & 1930 & & 1820 & & 1940 \\
\hline $\mathrm{Sr}$ & & 528 & & 675 & & 729 & & 574 \\
\hline $\mathrm{Ti}$ & $<$ & 14.9 & $<$ & 14.9 & $<$ & 14.4 & $<$ & 14.8 \\
\hline $\mathrm{U}$ & & 3390 & & 6180 & & 6080 & & 5140 \\
\hline $\mathrm{V}$ & & 408 & $<$ & 99.1 & & 113 & & 99.8 \\
\hline $\mathrm{Zn}$ & & 81.3 & & 144 & & 136 & & 107 \\
\hline $\mathrm{Zr}$ & & 25500 & & 6510 & & 10800 & & 5670 \\
\hline Th-232 ug/g & & $8.09^{*}$ & & & & & & \\
\hline U-235 ug/g & & & & 13.8 & & 12.3 & & 12.6 \\
\hline U-236 ug/g & & & & 1.30 & & & & 1.31 \\
\hline U-238 ug/g & & & & $2.77 E+03$ & & $2.50 E+03$ & & $2.46 E+03$ \\
\hline U enrichment & & & & 0.495493878 & & 0.489591211 & & 0.509315214 \\
\hline $\mathrm{Pu}-238$ (dpm/g) & & No data for blk & & $4.28 E+06$ & & $4.22 E+06$ & & $4.02 E+06$ \\
\hline Pu-239/240 (dpm/g) & & No data for blk & & $8.29 E+04$ & & $7.88+E 04$ & & $9.08 E+04$ \\
\hline
\end{tabular}



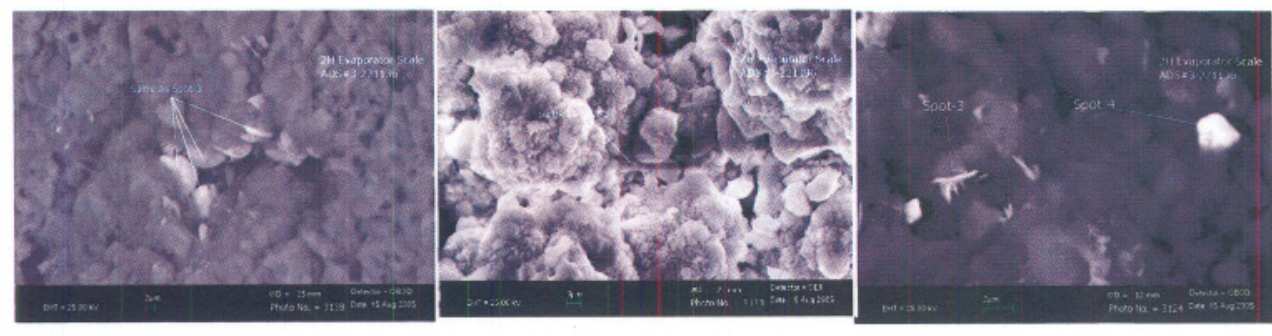

Figure 3. Scanning Electron Microscopy Images of the GDL Scale

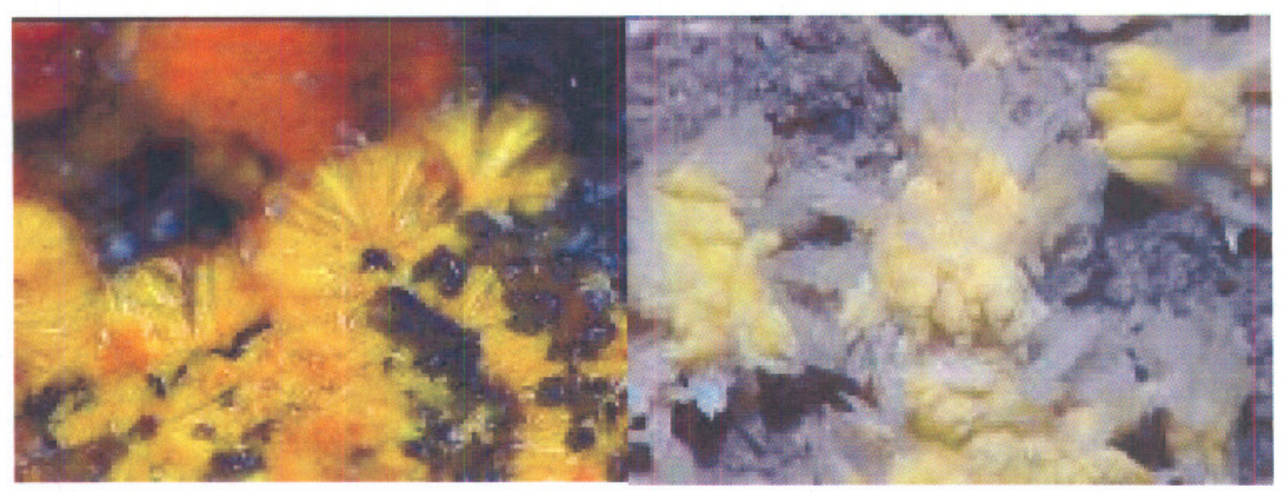

\section{Boltwoodite}

Weeksite

Figure 4. Scanning Electron Microscopy Images of Uranium Compounds
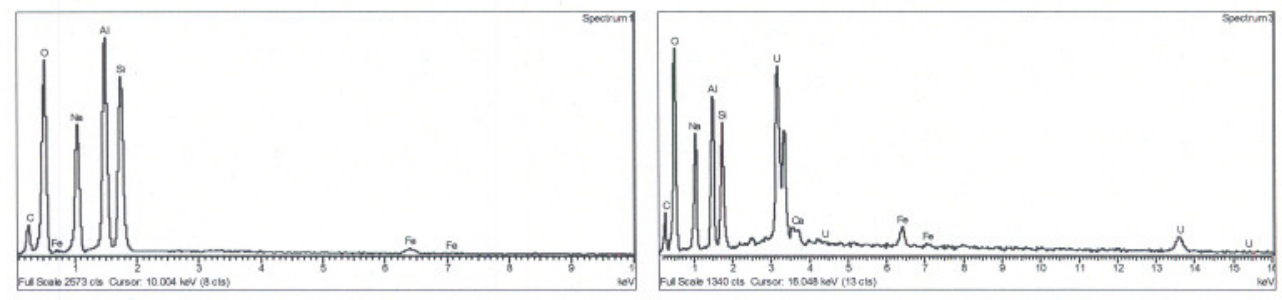

Figure 5. Energy Dispersive Spectra from the GDL Scale 


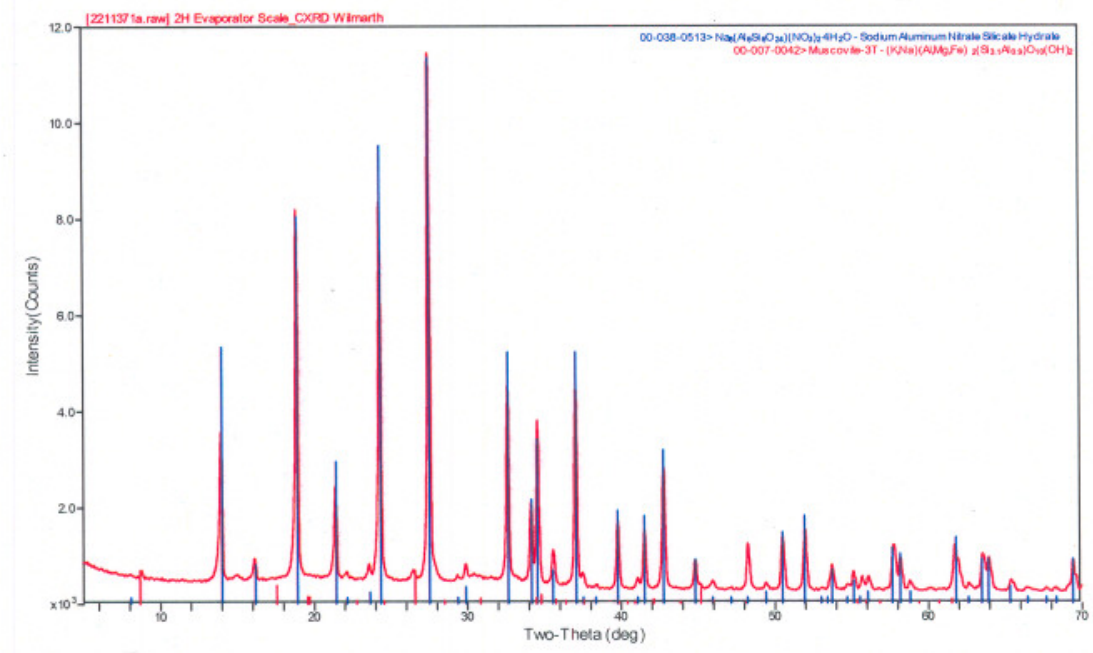

Figure 6. X-ray Powder Diffraction Pattern from the Gravity Drain Line Scale Sample

\section{Characterization Data for the Scale Samples from the 2H Evaporator Pot}

Three scale samples (HTF-137, HTF-138, and HTF-139) received at SRNL contained sufficient radioactivity to require processing in the shielded cells. HTF-139 is a sample from the warming coil. HTF-137 and HTF-138 are from the pot wall and tube bundle, respectively. The original focus of the evaporator pot sample characterization was fissile radionuclide content to support development of a Nuclear Criticality Safety Evaluation for pot cleaning.

The density of sample HTF-138 material was determined by water displacement to be $2.28 \mathrm{~g} / \mathrm{mL}(\sigma=0.51 \mathrm{~g} / \mathrm{mL}, \mathrm{n}=4)$. The $22 \%$ relative standard deviation of the HTF- 138 density is commensurate with the precision of the measurement method used. Density measurement was not performed on HTF-137 because the same method was not useable on a wet sample, and density measurement was not performed on HTF-139 due to lack of available sample. 
Page 14 of 26

Table 2 contains the radionuclide concentrations and applicable ICP-MS results for the three 2-H evaporator pot scale samples. Data are reported as the averages and standard deviations of the above-detection-limit values obtained from multiple preparations. Average detection limits are provided by considering only the analyses that were performed to minimize detection limits. Results are on an as-received basis (not a dry basis). Sample HTF-137 was taken from below the liquid level in the pot and had a wetter appearance than sample HTF-138.

Although the three samples varied in weight percentage of total uranium in the scale (from 0.483 to $2.01 \mathrm{wt} \%$ ), they had a consistent U-235 enrichment, averaging $0.502 \%$ ( $\sigma$ $=0.010 \%, \mathrm{n}=8)$.

Table 3 contains the ICP-ES data from the peroxide-fusion digestion of the evaporator scale samples. Note that this method introduces $\mathrm{Na}$ and $\mathrm{Zr}$ into the sample, and thus they are not reported. Historically, Ag introduction into the sample was also noted for peroxide fusion. The results are consistent with the bulk composition of the scale being sodium aluminosilicate, although Si results were scattered. Minor components detected in the scale include $\mathrm{Fe}, \mathrm{Ce}, \mathrm{Sn}$, and $\mathrm{Mn}$.

Based on the stoichiometry evident from the SEM and XRD results, the silicon values reported in Table 3 are likely biased low. Because it was not the focus of the original characterization scope, the sample preparation method was not optimized to keep silicon in solution for accurate measurement. Silicon content is likely closer to the 1:1 molar stoichiometric equivalent to the aluminum content. 
Page 15 of 26

Table 2: Radiochemistry and ICP-MS Results for the 2-Evaporator Pot Scale Samples

\begin{tabular}{|c|c|c|c|c|c|c|c|c|}
\hline & \multicolumn{2}{|c|}{ HTF-137 Pot Wall } & \multicolumn{2}{|c|}{ HTF-138 Tube Bundle } & \multicolumn{2}{|c|}{ HTF-139 Warming Coil } \\
\hline Analyte & Method & Units & average & st dev & average & st dev & average & st dev \\
\hline \multicolumn{9}{|c|}{ analyses to support evaporator chemical cleaning NCSE } \\
\hline Mass $233(\mathrm{U})$ & ICP-MS & wt $\%$ & $<4.95 E-05$ & - & $<2.01 E-04$ & -- & $<6.10 E-05$ & -- \\
\hline Mass 234 (U) & ICP-MS & wt $\%$ & $7.54 \mathrm{E}-05$ & $2.74 \mathrm{E}-05$ & 4.27E-04 & $5.7 \mathrm{E}-05$ & $7.35 \mathrm{E}-05$ & $9.3 \mathrm{E}-06$ \\
\hline Mass $235(\mathrm{U})$ & ICP-MS & wt $\%$ & $2.53 \mathrm{E}-03$ & $1.17 \mathrm{E}-03$ & $1.01 \mathrm{E}-02$ & $4.9 \mathrm{E}-03$ & $2.44 \mathrm{E}-03$ & $2.2 \mathrm{E}-04$ \\
\hline Mass $236(\mathrm{U})$ & ICP-MS & wt $\%$ & $1.60 \mathrm{E}-04$ & $7.3 \mathrm{E}-05$ & $8.65 \mathrm{E}-04$ & $1.18 \mathrm{E}-04$ & $1.71 \mathrm{E}-04$ & $1.9 \mathrm{E}-05$ \\
\hline Mass $238(\mathrm{U}, \mathrm{Pu})$ & ICP-MS & wt $\%$ & $4.96 \mathrm{E}-01$ & $2.27 \mathrm{E}-01$ & $2.00 \mathrm{E}+00$ & $9.5 \mathrm{E}-01$ & $4.80 \mathrm{E}-01$ & $2.8 \mathrm{E}-02$ \\
\hline Pu-239/240 & PuTTA & wt $\%$ & $1.38 \mathrm{E}-04$ & $5.6 \mathrm{E}-05$ & $3.51 \mathrm{E}-04$ & $2.14 \mathrm{E}-04$ & $1.33 \mathrm{E}-04$ & 7E-06 \\
\hline Pu-241 & $\mathrm{Pu}-241$ & $\mathrm{wt} \%$ & 4.13E-07 & $1.33 \mathrm{E}-07$ & $1.70 \mathrm{E}-06$ & $9.6 \mathrm{E}-07$ & $9.40 \mathrm{E}-07$ & $6.49 \mathrm{E}-07$ \\
\hline Total U & \begin{tabular}{|l|} 
calculation \\
\end{tabular} & wt $\%$ & 4.99E-01 & $2.28 \mathrm{E}-01$ & $2.01 \mathrm{E}+00$ & $9.6 \mathrm{E}-01$ & $4.83 \mathrm{E}-01$ & $2.9 \mathrm{E}-02$ \\
\hline U-235 enrichment & calculation & $\%$ & $0.505 \%$ & $0.003 \%$ & $0.496 \%$ & $0.012 \%$ & $0.505 \%$ & $0.016 \%$ \\
\hline \multicolumn{9}{|c|}{ additional analyses } \\
\hline Cs-137 & gamma & $\mathrm{dpm} / \mathrm{g}$ & $1.06 \mathrm{E}+08$ & $8 \mathrm{E}+06$ & $1.77 \mathrm{E}+08$ & $1.5 \mathrm{E}+07$ & $1.16 \mathrm{E}+08$ & $4 \mathrm{E}+06$ \\
\hline Cs-134 & gamma & $\mathrm{dpm} / \mathrm{g}$ & bdl & - & $2.97 \mathrm{E}+04$ & $3.0 \mathrm{E}+03$ & bdl & -- \\
\hline Co-60 & gamma & $\mathrm{dpm} / \mathrm{g}$ & $1.45 \mathrm{E}+04$ & $5.5 \mathrm{E}+03$ & $1.52 \mathrm{E}+04$ & $3.3 \mathrm{E}+03$ & bdl & -- \\
\hline Mass $232(\mathrm{Th})$ & ICP-MS & $\mathrm{wt} \%$ & $1.80 \mathrm{E}-04$ & $5.6 \mathrm{E}-05$ & $2.40 \mathrm{E}-04$ & -- & $2.40 \mathrm{E}-04$ & $1.8 \mathrm{E}-05$ \\
\hline Mass $237(\mathrm{~Np})$ & ICP-MS & wt \% & $1.36 \mathrm{E}-04$ & $6.3 \mathrm{E}-05$ & $6.43 \mathrm{E}-04$ & $5.9 \mathrm{E}-05$ & $1.39 \mathrm{E}-04$ & $4 \mathrm{E}-06$ \\
\hline $\mathrm{Pu}-238$ & PuTTA & $\mathrm{dpm} / \mathrm{g}$ & $2.87 \mathrm{E}+06$ & $7.1 \mathrm{E}+05$ & $1.27 \mathrm{E}+07$ & $7.0 \mathrm{E}+06$ & $6.14 \mathrm{E}+06$ & $3.95 \mathrm{E}+06$ \\
\hline Mass $239(\mathrm{Pu})$ & ICP-MS & wt $\%$ & $<8.00 E-04$ & - & $<8.00 E-04$ & - & $<8.00 E-04$ & - \\
\hline Mass $240(\mathrm{Pu})$ & ICP-MS & wt $\%$ & $<4.95 E-05$ & - & $<2.01 \mathrm{E}-04$ & -- & $<6.10 E-05$ & -- \\
\hline Mass $241(\mathrm{Pu}, \mathrm{Am})$ & ICP-MS & wt \% & $<4.95 E-05$ & - & $<2.01 E-04$ & -- & $<6.10 E-05$ & -- \\
\hline
\end{tabular}

$b d l=$ below detectable level 
Page 16 of 26

Table 3: ICP-ES Results for the 2-Evaporator Pot Scale Samples

\begin{tabular}{|c|c|c|c|c|c|c|}
\hline ICPES & $\mathrm{HTF}-137 \mathrm{Pc}$ & ot Wall & HTF-138 Tub & e Bundle & HTF-139 War & ning Coil \\
\hline$(w t \%)$ & average & st dev & average & st dev & average & st dev \\
\hline $\mathrm{Ag}^{*}$ & $1.44 \mathrm{E}-02$ & 2.2E-03 & $1.93 \mathrm{E}-02$ & $1.8 \mathrm{E}-03$ & 8.17E-02 & $1.92 \mathrm{E}-02$ \\
\hline $\mathrm{Al}$ & $1.11 \mathrm{E}+01$ & $1.2 \mathrm{E}+00$ & $1.22 \mathrm{E}+01$ & $1.7 \mathrm{E}+00$ & $1.23 \mathrm{E}+01$ & 6E-01 \\
\hline $\mathrm{B}$ & $<1.70 E-02$ & -- & $<1.66 E-02$ & -- & $<5.28 E-02$ & -- \\
\hline $\mathrm{Ba}$ & 5.23E-03 & - & $<3.59 E-03$ & - & $1.43 \mathrm{E}-02$ & $1.8 \mathrm{E}-03$ \\
\hline $\mathrm{Ca}$ & $1.04 \mathrm{E}-01$ & $1.1 \mathrm{E}-02$ & $1.74 \mathrm{E}-01$ & $3.0 \mathrm{E}-02$ & $3.18 \mathrm{E}-01$ & $8 \mathrm{E}-03$ \\
\hline $\mathrm{Cd}$ & $<3.99 E-03$ & -- & $<4.15 E-03$ & - & $<1.24 E-02$ & -- \\
\hline $\mathrm{Ce}$ & $1.68 \mathrm{E}-01$ & $6.3 \mathrm{E}-02$ & $1.21 \mathrm{E}-01$ & $2.3 \mathrm{E}-02$ & $6.25 \mathrm{E}-01$ & $6.2 \mathrm{E}-02$ \\
\hline $\mathrm{Cr}$ & $3.49 \mathrm{E}-02$ & $1.44 \mathrm{E}-02$ & $1.11 \mathrm{E}-02$ & -- & $<1.97 E-02$ & - \\
\hline $\mathrm{Cu}$ & $<1.22 E-03$ & -- & $<1.25 E-03$ & -- & $<3.77 E-03$ & -- \\
\hline $\mathrm{Fe}$ & $2.37 \mathrm{E}-01$ & $9.6 \mathrm{E}-02$ & $2.12 \mathrm{E}-01$ & $5.8 \mathrm{E}-02$ & $2.37 \mathrm{E}-01$ & 8.9E-02 \\
\hline Gd & 8.31E-03 & $3.01 \mathrm{E}-03$ & $7.01 \mathrm{E}-03$ & $2.94 \mathrm{E}-03$ & $3.28 \mathrm{E}-02$ & 2.7E-03 \\
\hline $\mathrm{K}$ & $<6.04 E-01$ & -- & $<8.56 E-01$ & -- & $<1.87 E+00$ & -- \\
\hline $\mathrm{La}$ & $2.84 \mathrm{E}-02$ & $1.30 \mathrm{E}-02$ & $2.16 \mathrm{E}-02$ & $6.9 \mathrm{E}-03$ & $9.86 \mathrm{E}-02$ & $9.1 \mathrm{E}-03$ \\
\hline $\mathrm{Li}$ & $<9.90 E-02$ & -- & $<1.14 E-01$ & -- & $<3.07 E-01$ & -- \\
\hline $\mathrm{Mg}$ & $<7.17 E-03$ & - & $<5.20 E-03$ & -- & $<2.22 E-02$ & -- \\
\hline $\mathrm{Mn}$ & $1.24 \mathrm{E}-02$ & $4.1 \mathrm{E}-03$ & $1.00 \mathrm{E}-02$ & $5.2 \mathrm{E}-03$ & $1.07 \mathrm{E}-02$ & $1.4 \mathrm{E}-03$ \\
\hline Mo & $<6.35 E-02$ & - & $<8.14 E-02$ & -- & $<1.97 E-01$ & - \\
\hline $\mathrm{Ni}$ & 2.73E-02 & -- & 2.15E-02 & -- & $<5.21 E-02$ & -- \\
\hline $\mathrm{P}$ & $<9.86 E-02$ & -- & $<1.13 E-01$ & -- & $<3.05 E-01$ & -- \\
\hline $\mathrm{Pb}$ & $<9.77 E-02$ & -- & $<1.38 E-01$ & -- & $<3.02 E-01$ & - \\
\hline $\mathrm{S}$ & $1.12 \mathrm{E}-01$ & -- & $<1.01 E-01$ & -- & $<2.90 E-01$ & - \\
\hline $\mathrm{Sb}$ & 7.83E-02 & -- & $<6.54 E-02$ & -- & $1.90 \mathrm{E}-01$ & -- \\
\hline $\mathrm{Si}$ & $3.20 \mathrm{E}+00$ & $1.61 \mathrm{E}+00$ & $3.71 \mathrm{E}+00$ & $1.33 \mathrm{E}+00$ & $1.54 \mathrm{E}+01$ & 5E-01 \\
\hline $\mathrm{Sn}$ & $1.90 \mathrm{E}-01$ & $6.1 \mathrm{E}-02$ & $1.47 \mathrm{E}-01$ & -- & $6.16 \mathrm{E}-01$ & $5.0 \mathrm{E}-02$ \\
\hline $\mathrm{Sr}$ & $3.35 \mathrm{E}-02$ & $6.3 \mathrm{E}-03$ & $4.11 \mathrm{E}-02$ & $1.01 \mathrm{E}-02$ & $1.09 \mathrm{E}-01$ & $5 \mathrm{E}-03$ \\
\hline $\mathrm{Ti}$ & $1.01 \mathrm{E}-03$ & $2.2 \mathrm{E}-04$ & 2.27E-03 & $1.18 \mathrm{E}-03$ & $4.61 \mathrm{E}-03$ & $2.6 \mathrm{E}-04$ \\
\hline $\mathrm{V}$ & $<1.27 E-01$ & -- & $<1.36 E-01$ & -- & $<3.93 E-01$ & -- \\
\hline $\mathrm{Zn}$ & $<1.27 E-02$ & -- & $<1.05 E-02$ & -- & $<3.95 E-02$ & -- \\
\hline
\end{tabular}

* likely introduced by the peroxide fusion dissolutions in $\mathrm{Zr}$ crucibles 
Figure 7 shows the X-ray powder pattern from an aliquot of the sample HTF-137 which was removed from the pot wall. The X-ray powder pattern shows diffraction peaks from three crystalline species and includes cancrinite (pattern number 038-0513), a dehydrated zeolite of the same aluminum and silicon stoichiometry (pattern number 050-0248) and muscovite (pattern number 007-0042). The distinguishing feature of this pattern from that previously measured from either scale removed from the evaporator pot or the gravity drain line is the presence of the dehydrated zeolite. The diffraction peak intensity of the cancrinite and dehydrated zeolite reflections are nearly equal and can qualitatively indicate that the two crystalline phases are of equal concentration in the scale. This was not observed in the characterization of the samples previously removed from the evaporator pot wall. ${ }^{2,3}$ The dehydrated phase was probably present in the $2 \mathrm{H}$ Evaporator during the 2001 cleaning but went undetected during characterization activities.

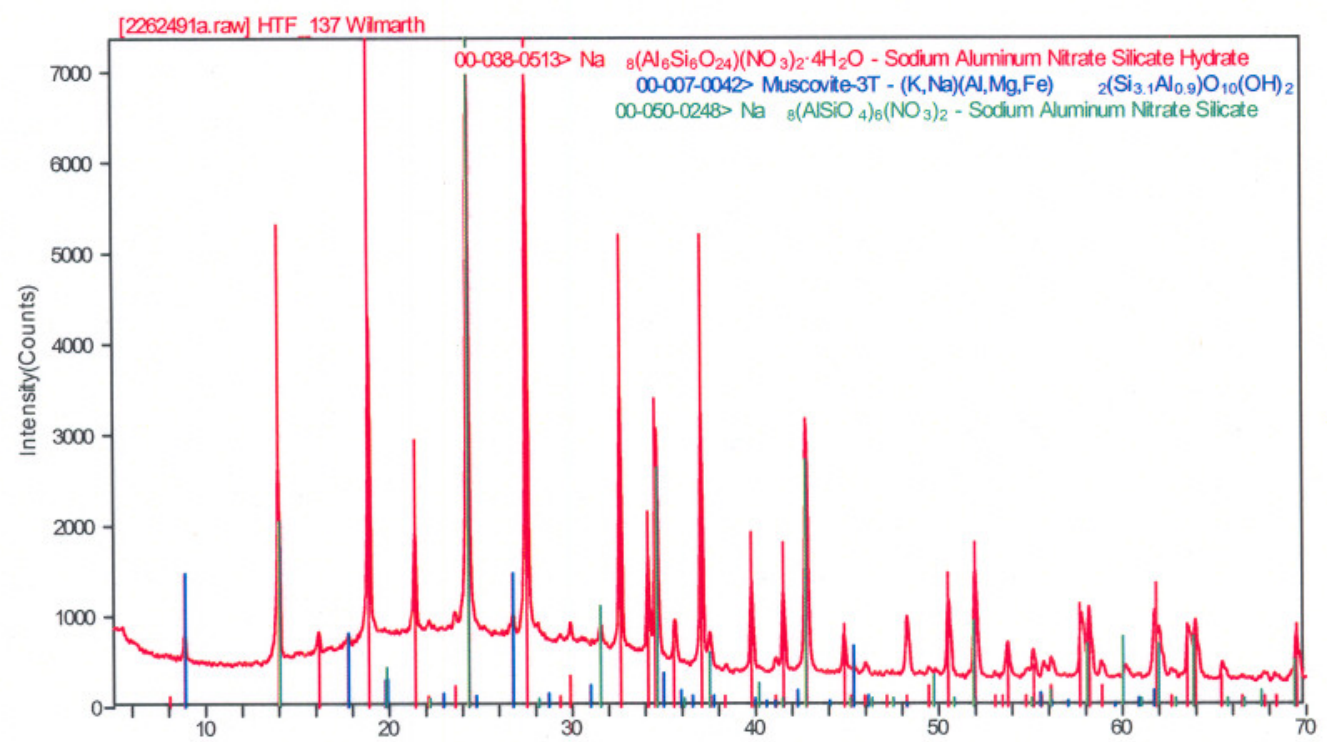

Figure 7. Typical X-ray Diffraction Powder Pattern obtained from the Samples from the $2 \mathrm{H}$ Evaporator Pot

Figure 8 through Figure 11 contain the SEM and XEDS results for a single grain of ground scale taken from the tube bundle of the $2 \mathrm{H}$-evaporator pot (HTF-138). The localized bright areas in the SEM backscatter detector images (Figure 8, bottom images of Figure 9 and Figure 10) correspond to uranium-rich particles (see the bottom XEDS spectrum in Figure 11). The bulk of the material, which is medium gray in the SEM backscatter detector images, is consistent with sodium aluminosilicate and is relatively free of uranium (see the top XEDS spectrum in Figure 11). From the SEM secondary electron images, regions of string-like structures are evident in both the uranium rich and sodium aluminosilicate phases. 

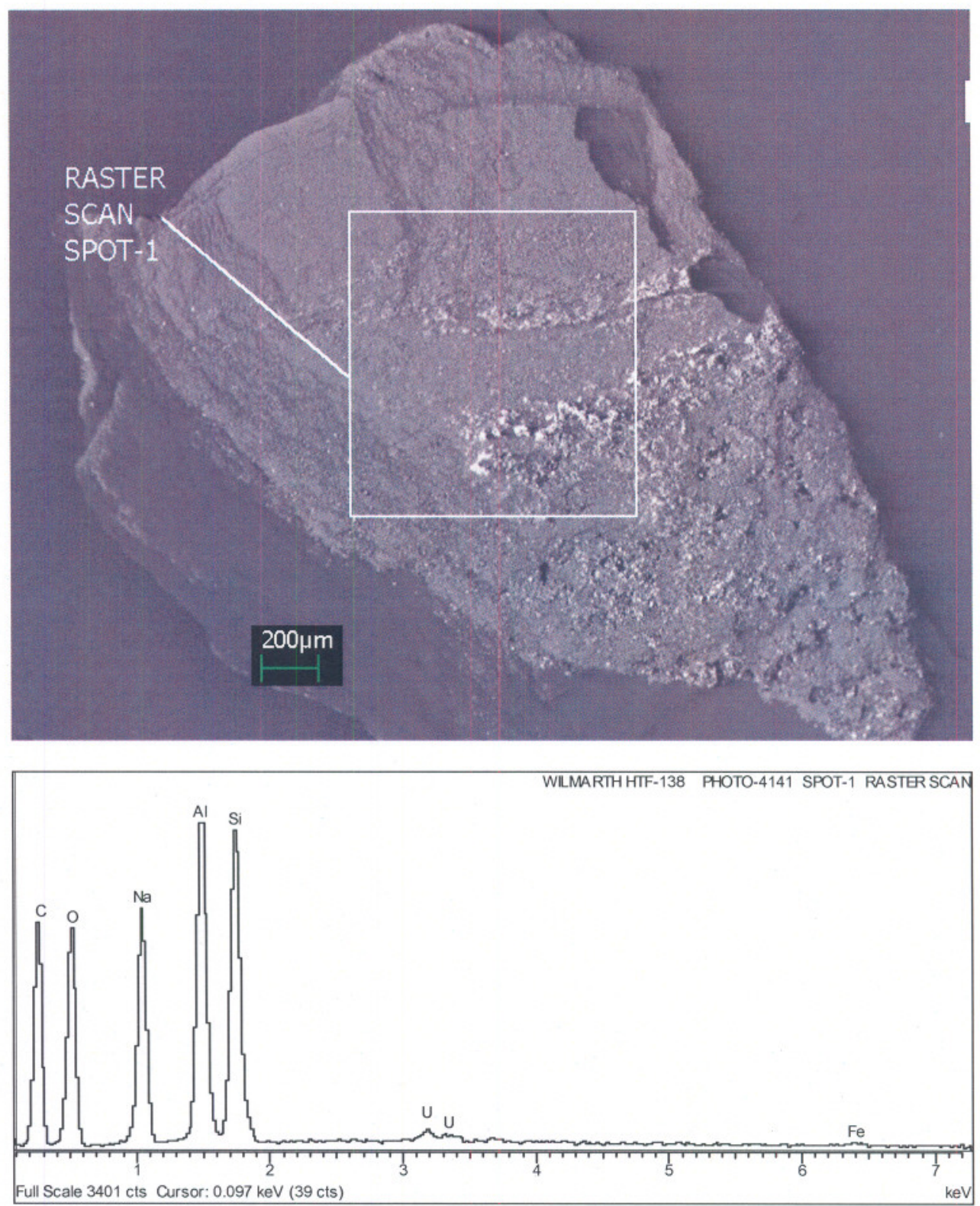

Figure 8: Top: SEM backscatter detector image of a coated grain of scale from the tube bundle (sample HTF-138). Bottom: the corresponding XEDS raster scan of an area of the grain. 
Page 19 of 26
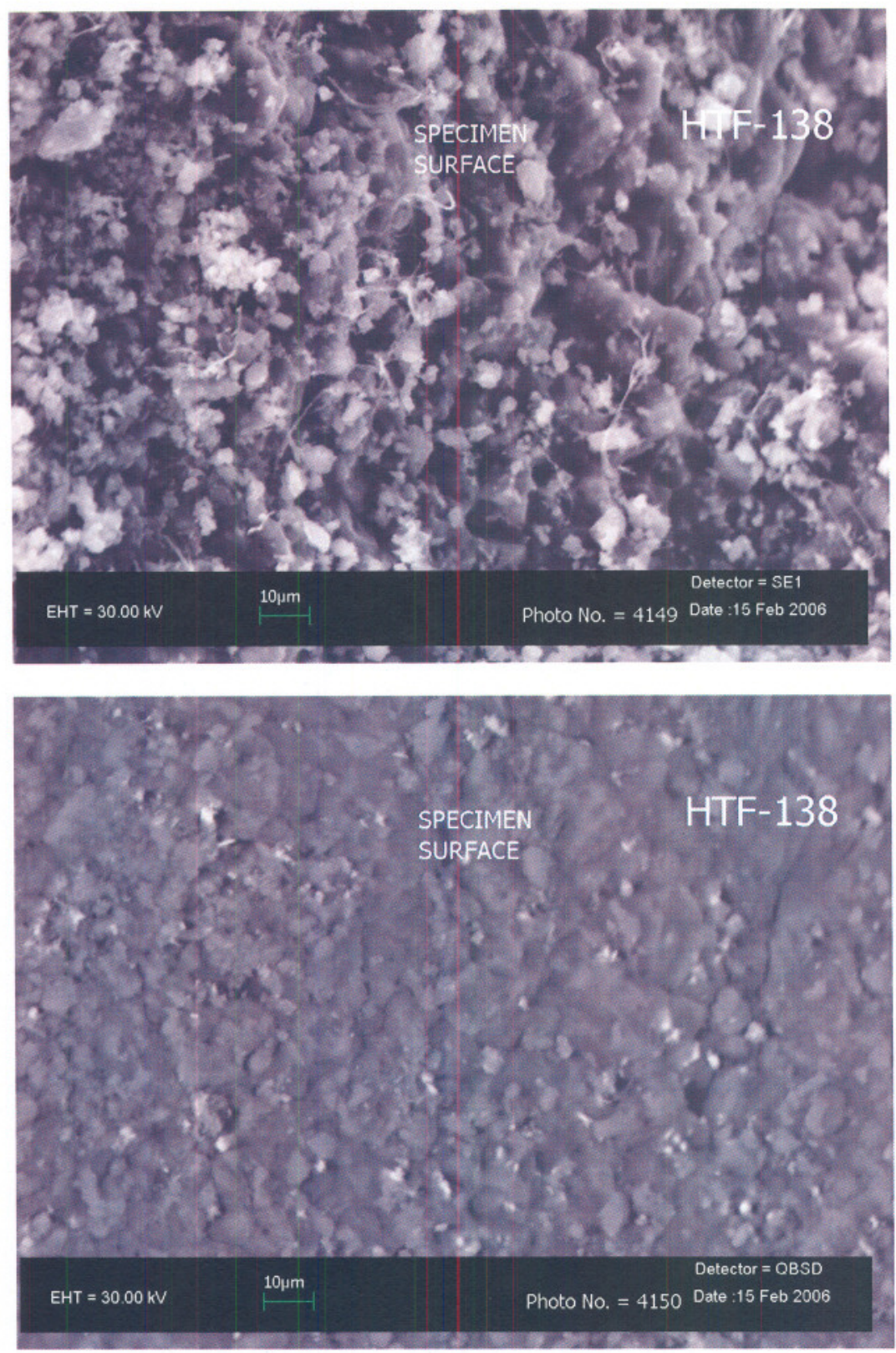

Figure 9: SEM secondary electron (top) and backscatter (bottom) images of the surface of a grain of scale from the evaporator tube bundle (HTF-138), magnified 650X. 
Page 20 of 26
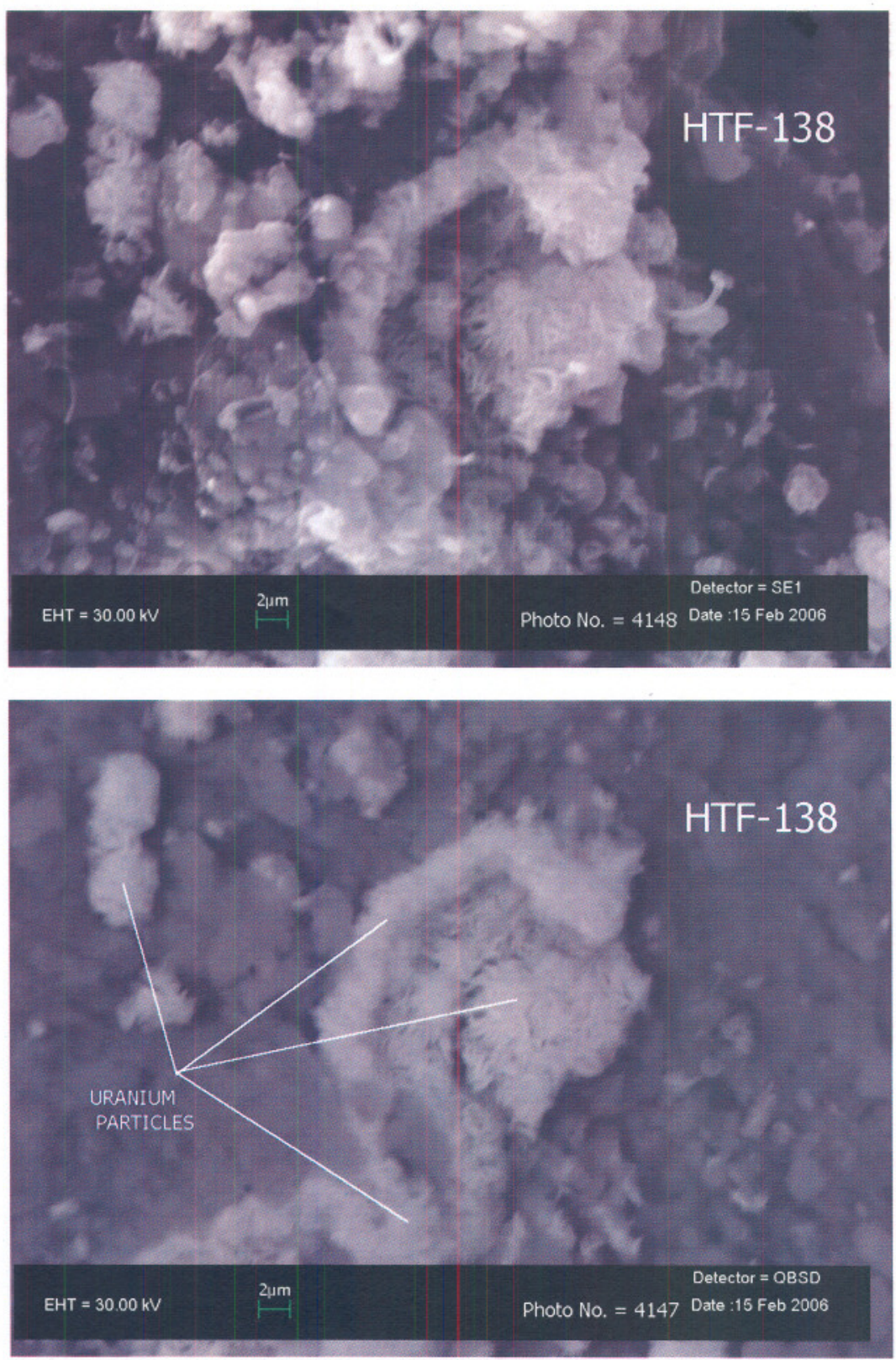

Figure 10: SEM secondary electron (top) and backscatter (bottom) images of the surface of a grain of scale from the evaporator tube bundle (HTF-138), magnified 2000X. 
Page 21 of 26
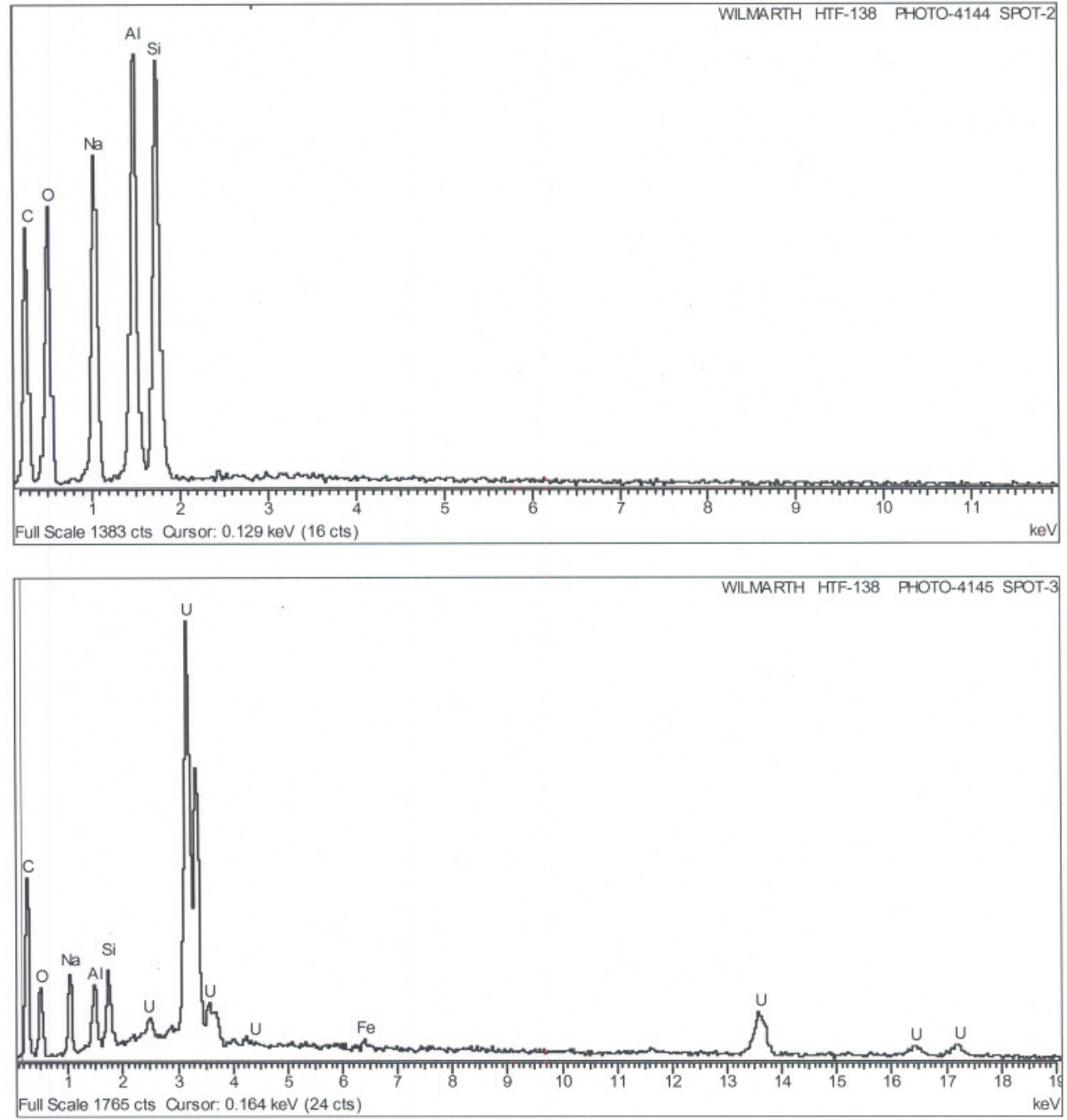

Figure 11: Localized XEDS spectra for the uranium-free sodium-aluminosilicate areas (top) and uranium-rich areas (bottom) of the 2-H evaporator tube bundle scale.

\section{Dissolution Studies of the Gravity Drain Line Scale}

Shown in Figure 12 are the measured concentrations of aluminum from testing ranging from $0.5 \mathrm{M}$ to $19 \mathrm{M}$ sodium hydroxide as the dissolving solvent. The testing duration for each of these tests was 4 hours. A linear increase in aluminum concentration was observed during these 4 hours. With solids still remaining at the conclusion of the tests and the measured silicon and aluminum concentrations were continuing to increase, there 
Page 22 of 26

is no indication that dissolution was complete in any of these tests. The amount of aluminum dissolved per unit time at $90{ }^{\circ} \mathrm{C}$ was directly proportional to the concentration of sodium hydroxide with the rate of dissolution at $0.5 \mathrm{M} \mathrm{NaOH}$ being $18 \mathrm{mg} \mathrm{Al} / \mathrm{h}$ and at $19 \mathrm{M} \mathrm{NaOH}$ being $63 \mathrm{mg} \mathrm{Al} / \mathrm{h}$.

Figure 13 shows the similar set of results for the measured silicon concentrations rather than aluminum. Silicon dissolves into the various caustic solutions to a larger degree than does aluminum with the exception of the $19 \mathrm{M} \mathrm{NaOH}$ solution. This has been observed in the past. ${ }^{18}$ The highest silicon dissolution rate was observed at $90{ }^{\circ} \mathrm{C}$ in the 8 $\mathrm{M}$ sodium hydroxide solution and measured $200 \mathrm{mg} \mathrm{Si} / \mathrm{h}$. The aluminum precipitates most likely as gibbsite, boehmite or sodium aluminate. In test with the $8 \mathrm{M}$ sodium hydroxide, the four hour data for both aluminum and silicon appears low and thus rates were calculated from the three hour data points. Additionally, in the testing with the 19 $\mathrm{M}$ sodium hydroxide, a gel formed in the dissolution beaker. Figure 14 shows a photograph of the gel that was produced.

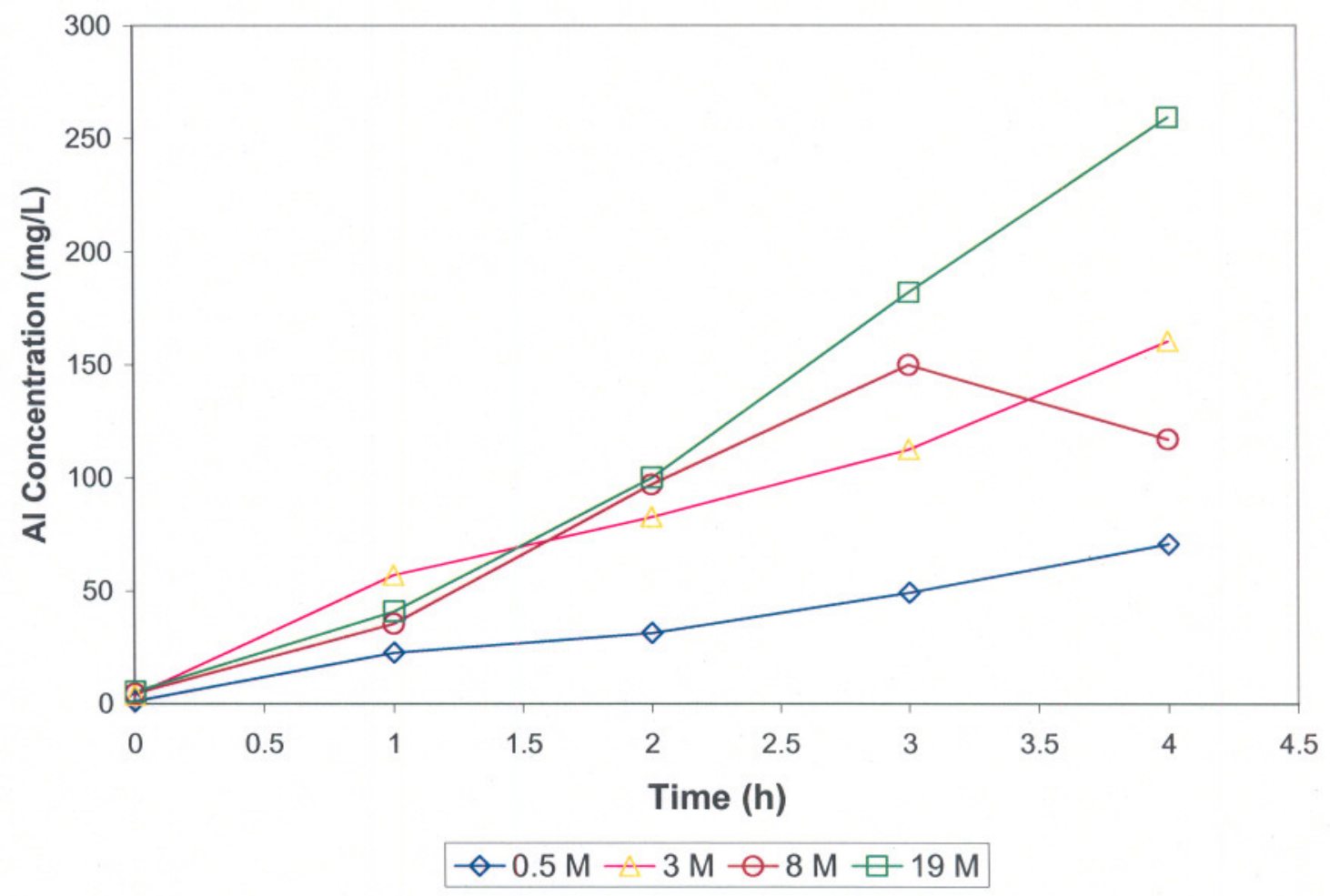

Figure 12. Aluminum Dissolution Data in Various Caustic Solutions 
Page 23 of 26

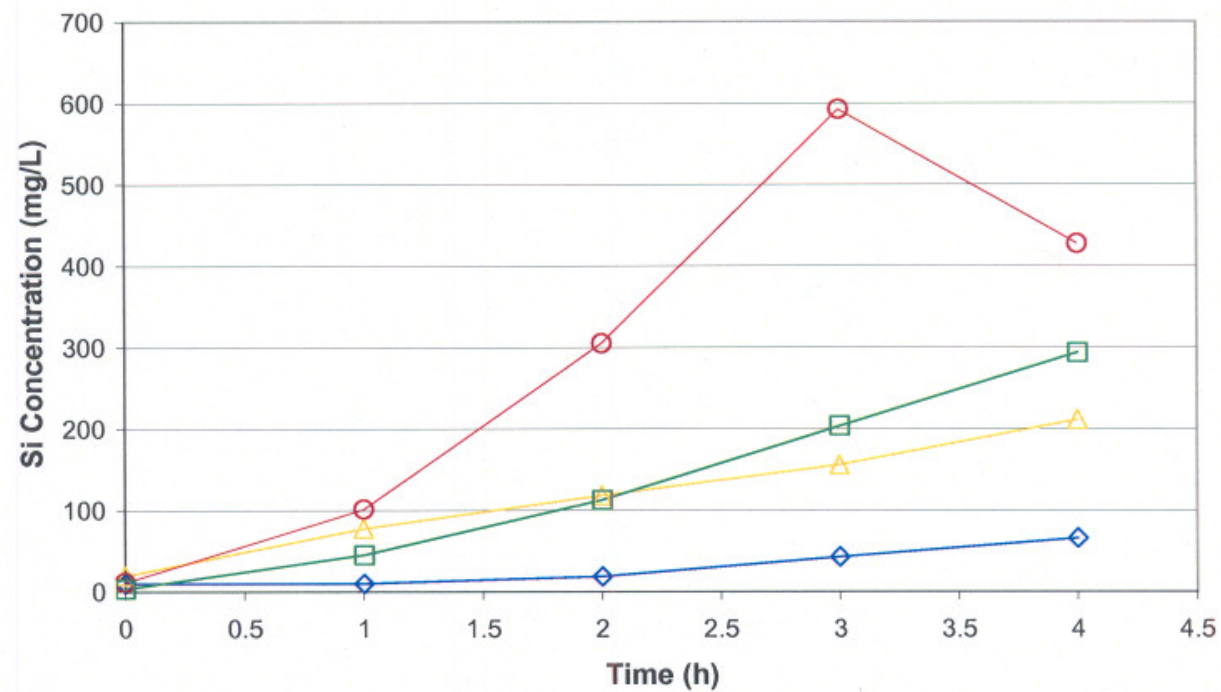

$\diamond 0.5 \mathrm{M} \triangle 3 \mathrm{M}-8 \mathrm{M} \square 19 \mathrm{M}$

Figure 13. Silicon Dissolution Data at Various Caustic Concentrations

Shown in Figure 15 is a graphical comparison of the results from dissolution testing in 3 $\mathrm{M}$ sodium hydroxide solution for an aliquot of a scale sample removed from the Gravity Drain Line in 1997 and the sample removed in 2005. It is evident that the amount of silicon that dissolved from the 1997 scale sample is significantly higher than that which dissolved from the 2005 scale. Reasons for this difference could include different particle sizes because the samples were taken with different sampling tools, different surface area and porosity of the samples that entered the testing, and the two scales dissolution rates. If the scales do actual dissolve at significantly different rates, the facility will have to use higher caustic concentrations than the planned $3 \mathrm{M}$ sodium hydroxide and/or the facility will have to increase the caustic soak time in the pot to much longer times than the flowsheet duration of 8 hours. 
Page 24 of 26

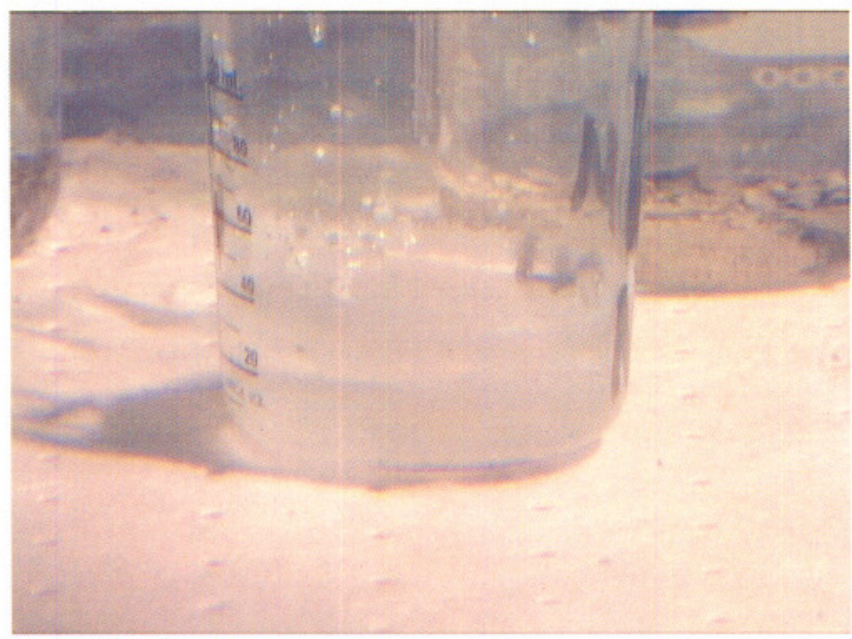

Figure 14. Gelation of Test with $19 \mathrm{M}$ Sodium Hydroxide

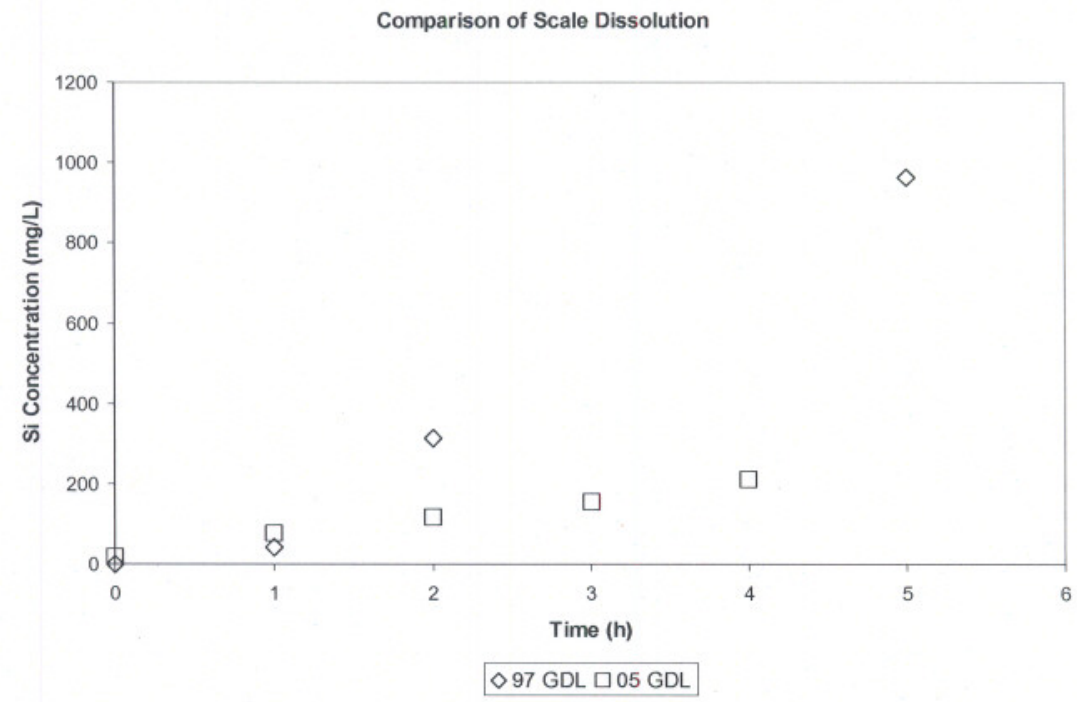

Figure 15. Comparison of the Dissolution of GDL Scale Samples 


\section{Conclusions}

The formation of sodium aluminosilicate (NAS) scale in the high-level-waste evaporator continues to persist during the processing of recycle water from the Defense Waste Processing Facility. Scale removed from the $2 \mathrm{H}$ Evaporator system (gravity drain line and the evaporator pot) continue to show inclusion of uranium into the scale matrix. With the increased sampling within the evaporator pot, one notices that the amount of uranium in the tube bundle sample $(2.01 \mathrm{wt} \%)$ is higher than the gravity drain line sample $(0.498 \mathrm{wt} \%)$, the wall sample $(0.499 \mathrm{wt} \%)$ and the warming coil sample $(0.48$ wt $\%$ ). The uranium enrichment in all samples was nearly identical and measured $0.5 \%$. The higher amounts of uranium in the sample from the tube bundle may be related to the higher temperature and higher degree of evaporation that takes place at the surface of the tube bundle. X-ray diffraction analysis of these samples shows the traditional crystallographic phase found previously in the late 1990s and in early 2000. This phase is the hydrated and nitrated phase of cancrinite. A second phase observed in the analysis of the scale removed from the tube bundle is the dehydrated zeolytic phase which has not been named. This phase is likely denser than the cancrinite phase. However, the phase was most likely present during the cleaning operations conducted in 2001 but was not observed in the samples taken from the pot wall.

Dissolution testing of the scale removed from the gravity drain line show that the scale would dissolve in sodium hydroxide solutions ranging from $0.5 \mathrm{M}$ to $19 \mathrm{M}$ at elevated temperature $\left(90^{\circ} \mathrm{C}\right)$. This dissolution is relatively slow but increases with increasing caustic concentration. Care must be used to avoid gel formation at very high caustic concentrations. This work suggested that for implementation in the $2 \mathrm{H}$ Evaporator that a sodium hydroxide cleaning solution should be on the order of $3-8 \mathrm{M} \mathrm{NaOH}$. Contrary to the acid cleaning flowsheet in which aluminum and silicon initially dissolve and the silicon eventually precipitates, the behavior in caustic is just the opposite. Both metals initially dissolve into the caustic cleaning solution. In sodium hydroxide, the aluminum eventually precipitates allowing further dissolution of the silicon from the aluminosilicate scale. 


\section{References}

${ }^{1}$ W. R. Wilmarth, M. C. Thompson, C. J. Martino, V. H. Dukes, J. T. Mills, C. Boley, and B. L. Lewis, "Nitric Acid Cleaning of a Sodalite - Sodium Diuranate Scale in High Level Waste Evaporators," WSRC-MS-2001-00741, Rev. 0, October 4, 2001.

${ }^{2}$ W. R. Wilmarth, C. J. Coleman, J. C. Hart, and W. T. Boyce, "Characterization of Samples from the 242-16H Evaporator Wall," WSRC-TR-2000-00089, March 20, 2000

${ }^{3}$ W. R. Wilmarth, C. J. Coleman, A. R. Jurgensen, W. M. Smith, J. C. Hart, W. T. Boyce, D. Missmer, and C. M. Conley, "Characterization and Dissolution Studies of Samples from the 242-16H Evaporator," WSRC-TR-2000-00038, Rev. 0, January 31, 2000.

${ }^{4}$ Barnes, M. C.; Addai-Mensah, J.; Gerson, A. R. J., Crystal Growth, 200 (1999), 251264.

${ }^{5}$ Gasteiger, H. A.; Fredrick, W. J.; Streisel, R. C., J. Eng. Chem. Res., Vol 31, 1992, 1190 .

${ }^{6}$ Buhl, J.; Löns, J., J. Alloys and Compounds, 235 (1996), 41.

${ }^{7}$ Kumada, N.; Wetrum, E. F.; Hemingway, B. S.; Zolotov, M. Y.; Semenov, Y. V.; Khodakovsky, I. L.; Anovitz, L. M., J. Chem. Thermodynamics, 1995, 27, 1119.

${ }^{8}$ W. R. Wilmarth, M. C. Thompson, C. J. Martino, V. H. Dukes, J. T. Mills, C. Boley, and B. L. Lewis, "Nitric Acid Cleaning of a Sodalite - Sodium Diuranate Scale in High Level Waste Evaporators," WSRC-MS-2001-00741, Rev. 0, October 4, 2001.

${ }^{9}$ C. S. Boley, M. C. Thompson, W. R. Wilmarth, K. G. Brown, "Technical Basis for the 242-16H Evaporator Cleaning Process (U)," WSRC-TR-2000-00211, Rev. 1, November 7,2000.

${ }^{10}$ W. R. Wilmarth, "Technical Requirements for Dispositioning Tank 40H Decants, SRT-LWP-2001-00032, Rev. 1, March 20, 2001.

"J. Jeffrey, "2H Scale Sample Analysis," HLE-TTR-2005-057, Rev. 0, April 28, 2005.

${ }^{12}$ Manual L16.1, Procedure ADS-1564, "Contained Inductively Coupled Plasma Emission Spectrometer for Radioactive Sample Analysis JY170C (U), Rev. 2, September 30, 2003.

${ }^{13}$ Manual L16.1, Procedure ADS-2453, "Plutonium TTA Separation and Alpha Analysis," Rev. 2, December 14, 2002.

${ }^{14}$ Manual L16.1, Procedure ADS-1553, "Inductively Coupled Plasma Mass Spectrometer Elemental and Isotopic Analysis for Aqueous Liquid Samples Fisions Plasmaquad PQS972 II (U) RADICPMS,” Rev. 3, September 15, 2002.

${ }^{15}$ W. R. Wilmarth, S. D. Fink, D. T. Hobbs, and M. S. Hay, "Characterization and Dissolution Studies of Samples from the 242-16H Evaporator Gravity Drain Line (U)," WSRC-TR-97-0326, Rev. 0, October 16, 1997.

${ }^{16}$ J. Addai-Mensah, J. Li, M Zbik, S Rosencrance, "The Chemistry, Crystallization, Physiochemical Properties, and Behavior of Sodium Aluminosilicate Phases: Final Report," WSRC-MS-2002-00907, November 20, 2002.

${ }^{17}$ L. N. Oji and A. L. Williams, "Evaluation of the Incorporation of Uranium into Sodium Aluminosilicate Phases," WSRC-TR-2002-00527, November 20, 2002.

${ }^{18}$ W. R. Wilmarth, V. H. Dukes, J. T. Mills, T. B. Edwards, "Results of Aluminosilicate Formation Testing," WSRC-TR-2001-00330, July 13, 2001. 